\title{
Response of vegetation to growing recreational pressure in the shallow Raczyńskie Lake
}

\author{
Joanna Rosińska* and Ryszard Gołdyn \\ Department of Water Protection, Faculty of Biology, Adam Mickiewicz University, Umultowska 89, 61-614 Poznań, Poland
}

\begin{abstract}
Strong human impact accelerates eutrophication which deteriorates water quality and consequently prevents recreational use. Increasing trophy and low transparency induce macrophyte rebuilding. A gradual transformation of the land use of the direct catchment area of Raczyńskie Lake from agricultural to recreational has been observed over the last 45 years. In built-up areas sewage facilities were inadequate and septic tanks did not work properly and as a consequence most wastewater was able to infiltrate through the ground into the lake. The lake ecosystem became unstable and water blooms intensified. The aim of the study was to assess the changes in the composition of the lake vegetation over the last 45 years, during which the use of the direct catchment has changed and recreational pressure increased. A reduction of the number of plant communities from 24 to 15 and the disappearance of almost all the submerged vegetation was observed. The dominant reed beds (Phragmitetum communis, Typhetum angustifoliae) were unable to provide a sufficient barrier to the flow of pollution from the catchment because of the numerous gaps made for angling piers, bathing sites, jetties, etc. The macrophyte index indicated a bad ecological status. To improve the ecological status of Raczyńskie Lake it is necessary to introduce intensive protection and restoration treatments.
\end{abstract}

Keywords: macrophyte community / submerged macrophyte / human impact / recreation / WFD

Résumé - Réponse de la végétation à la pression récréative croissante dans le lac peu profond Raczyński. Un fort impact humain accélère l'eutrophisation, ce qui détériore la qualité de l'eau et, par conséquent, empêche l'utilisation récréative. L'augmentation de trophie et la faible transparence induisent la dégradation des macrophytes. Au cours des 45 dernières années, on a observé une transformation graduelle de l'utilisation des terres du bassin versant proche du lac Raczynskie, qui est passé de l'agriculture aux loisirs. Dans les zones bâties, les installations d'égouts étaient inadéquates et les fosses septiques ne fonctionnaient pas correctement, de sorte que la plupart des eaux usées pouvaient s'infiltrer dans le lac par le sol. L'écosystème du lac est devenu instable et la prolifération d'algues s'est intensifiée. L'objectif de l'étude était d'évaluer les changements dans la composition de la végétation lacustre pendant les 45 dernières années, au cours desquelles l'utilisation du bassin versant a changé et la pression récréative a augmenté. On a observé une réduction du nombre de communautés végétales de 24 à 15 et la disparition de presque toute la végétation submergée. Les roselières dominantes (Phragmitetum communis, Typhetum angustifoliae) n'ont pas été en mesure de fournir une barrière suffisante à l'écoulement de la pollution du bassin versant en raison des nombreuses brèches faites pour les pontons de pêche, les sites de baignade, les jetées, etc. L'indice des macrophytes indique un mauvais état écologique. Pour améliorer l'état écologique du lac Raczynskie, il est nécessaire d'introduire des traitements intensifs de protection et de restauration.

Mots-clés : communauté des macrophytes / macrophytes submergés / impact humain / loisirs / DCE

\footnotetext{
*Corresponding author: rosinska.asia@gmail.com
} 


\section{Introduction}

Lakes situated in the vicinity of large cities are valuable elements of landscape and offer attractive places for recreation. Dense recreational centers or summer and residential houses built within a short distance of the lake shore increase the number of people and enhance their pressure on the lake (Schmieder, 2004; Hall and Härkönen, 2006). Gradual transformations of the direct catchment area management of many lakes are observed, which mainly involve the conversion of fields and forests into recreational or residential use. These areas are frequently lack adequate sewerage, having only septic tanks which may fail to work properly, thus most of the wastewater infiltrates through the ground into the lake (Hall and Härkönen, 2006). Such usage brings about an acceleration of eutrophication and the aquatic ecosystem becomes extremely degraded (Zuccarini et al., 2011; Barałkiewicz et al., 2014; Grochowska et al., 2015). The lake can no longer be used recreationally (Dunalska et al., 2015) and most of the other ecosystem services are also lost (Xu et al., 2014). A change of color and odor of water, low transparency and strong phytoplankton bloom occur. In addition, direct human pressure, such as mowing or permanently removing plants for creating numerous gaps for angling piers, beaches, bathing sites, jetties. has a significant effect on vegetation (restructuring of phytocoenoses) in the littoral zone of the lake. The influence of such recreational human pressure on the lake status and especially on macrophytes is still poorly documented.

The occurrence of macrophytes depends on many environmental parameters, i.a. water movement, substrate type, light conditions, availability of nutrients and hydromorphological changes (Jusik and Macioł, 2014; Nagengast and Kuczyńska-Kippen, 2015). Catchment usage i.e. share of forests, farmlands, intensive recreational use and the presence of point nutrient sources is considered to be one of the most important elements that influence plants in stagnant waters (Sender, 2012). Aquatic plants integrate the temporal, spatial, chemical, physical and biological features of the ecosystem. Their distribution and abundance reflect changing conditions in the lake (Penning et al., 2008; Lombardo et al., 2013; Ciecierska and Kolada, 2014).

Therefore, the aim of our study was to evaluate the changes in the composition of macrophyte communities in a shallow lake over the last 45 years, where gradual changes of various recreational pressures in the area surrounding the lake and in its littoral zone were observed, leading to a deterioration of water quality.

\section{Materials and methods}

Raczyńskie Lake $\left(52^{\circ} 08^{\prime} 36^{\prime \prime} \mathrm{N} 17^{\circ} 09^{\prime} 56^{\prime \prime} \mathrm{E}\right)$, located in Zaniemyśl ( $35 \mathrm{~km}$ east-south of Poznań, Western Poland), is a typical example of a highly degraded lake used for several forms of recreation. It is the first lake located within the Kórnickie Lakes Chanel (Pułyk and Tybiszewska, 2002). It is a shallow hypereutrophic lake, without thermal stratification (Tab. 1). There are two basins separated by a peninsula and an island in the deeper basin (Gołdyn, 1975). The lake is very susceptible to external pollution, because it has no sufficient
Table 1. Morphometry of Raczyńskie Lake (Pułyk and Tybiszewska, 2002).

\begin{tabular}{ll}
\hline Parameter & Value \\
\hline Lake area & $84.4 \mathrm{ha}$ \\
Maximum depth & $5.8 \mathrm{~m}$ \\
Mean depth & $2.8 \mathrm{~m}$ \\
Total catchment area & $9.15 \mathrm{~km}^{2}$ \\
Length of shoreline & $6225 \mathrm{~m}$ \\
Maximum length of the lake & $2190 \mathrm{~m}$ \\
Maximum width of the lake & $610 \mathrm{~m}$ \\
Category of vulnerability to degradation & III \\
Area of island & 3.1 ha \\
Fish type classification & Zander type \\
\hline
\end{tabular}

natural protective barriers connected with morphometric parameters (third category of vulnerability to degradation, Tab. 1). The lake is supplied by several small, mostly seasonal tributaries and is drained by the Kamionka Stream, outflowing from the north-western part of the lake (Gołdyn, 1975). The changes in the land use of catchment area of Raczyńskie Lake (increase of built-up and recreational area), which were observed over the years, have been described in detail in the Result section.

The water quality of the lake was included in the $\beta$-mezosaprobic and eutrophic group in the early $1970 \mathrm{~s}, \mathrm{COD}_{\mathrm{Mn}}$ varied between $8.7-30.0 \mathrm{mg} \mathrm{O}_{2} \mathrm{~L}^{-1}$, concentration of nitrites

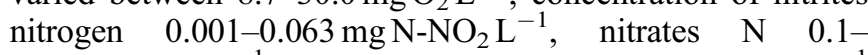

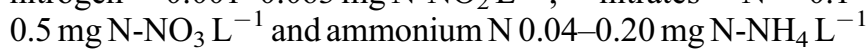
(Gołdyn, 1975). It has been repeatedly monitored by the Regional Inspectorate for Environmental Protection since 1973. In the years $1973 / 1974$ the water was classified into the third class of purity. It was identified as beyond class III in 1996 and similarly five years later. The results of conductivity showed a high and increasing concentration of mineral salts including nutrients, which influence high productivity of the lake. Symptoms of bad water condition have been observed from the 1990s, such as diatoms-cryptophyte blooms in spring and cyanobacterial blooms in summer (Pułyk and Tybiszewska, 2002). The ecological status of the lake calculated according to the Water Framework Directive (WFD) (Ordinance of the Minister of Environment, 2011) was bad in 2011 (Pułyk, 2012). Two years later the ecological status was also assessed as bad based on biological (class V) and physicochemical variables (below good status) such as transparency, total nitrogen and total phosphorus (Pułyk and Koziarska, 2014) (Tab. 2).

Although lake water aeration began in 1989, intensified from 1998 (Pułyk and Tybiszewska, 2002), and sewage management covering all built-up areas was introduced, the water quality was still bad. Strong cyanobacterial blooms occurred constantly (Pułyk and Koziarska, 2014) indicating a turbid stable state (Scheffer et al., 1993). The main source of nutrients originated from: (i) pollution from the catchment, i.e. groundwater inflow from soils polluted in the past by sewage from the leaky septic tanks of summer houses, (ii) increasing use of recreational areas at a short distance from the lake, (iii) 
J. Rosińska and R. Gołdyn: Knowl. Manag. Aquat. Ecosyst. 2018, 419, 1

Table 2. The water quality of Raczyńskie Lake in selected years (Pułyk and Buczyńska, 1997; Pułyk, 2012; Pułyk and Koziarska, 2014).

\begin{tabular}{lccrr}
\hline Parameters & $1996^{*}$ & $2011^{* *}$ & $2013^{* *}$ & $2015^{* *}$ \\
\hline Total phosphorus $\left(\mathrm{mg} \mathrm{P} \mathrm{L}^{-1}\right)$ & 0.16 & 0.25 & 0.19 & 0.17 \\
Total nitrogen $\left(\mathrm{mg} \mathrm{N} \mathrm{L}^{-1}\right)$ & 4.87 & 3.29 & 3.87 & 4.70 \\
The oxygen above the bottom $\left(\mathrm{mg} \mathrm{O}_{2} \mathrm{~L}^{-1}\right)$ & 0.30 & 2.90 & 5.60 & 0.10 \\
Chlorophyll $a\left(\mu \mathrm{g} \mathrm{L}^{-1}\right)$ & 112.6 & 99.7 & - & 115.0 \\
Transparency $(\mathrm{m})$ & 0.7 & 0.7 & 0.6 & 0.6 \\
\hline
\end{tabular}

${ }^{*}$ Mean of values from spring and summer at the surface layer (with the exception of the concentration of oxygen above the bottom).

** Annual mean of values at the surface layer (with the exception of the concentration of oxygen above the bottom).
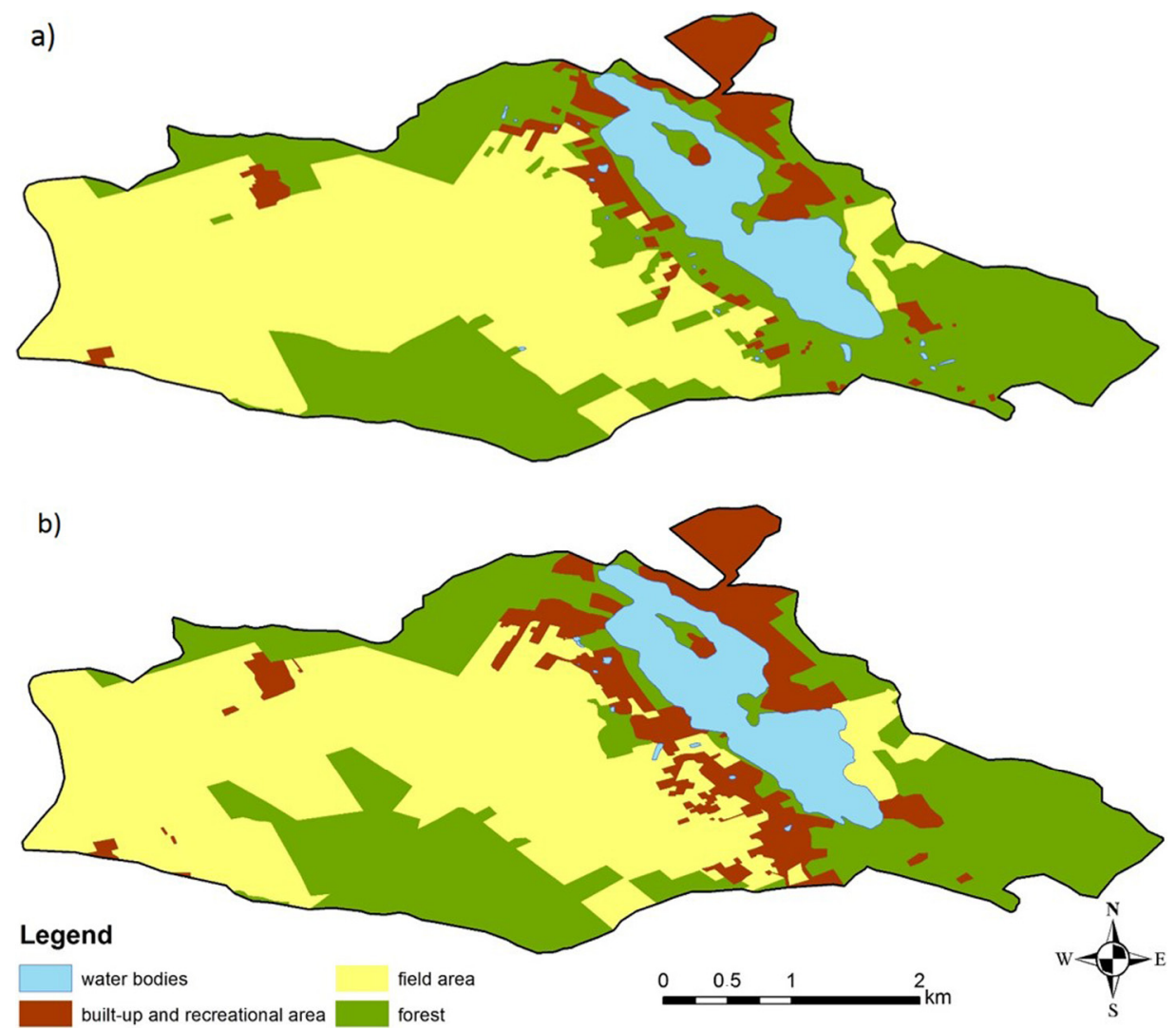

Fig. 1. Land use of Raczyńskie Lake catchment in the 1980s (a) and in 2015 (b).

surface runoff of stormwater from impervious areas in the catchment, (iv) fertilizers used in agriculture, as well as (v) internal loading from bottom sediments.

To compare changes in the use of catchment area over the years maps of land use were prepared with ArcGIS for Desktop 10.5.1 programme based on a topographic map (1980s) and an orthophotomap (2015) (Fig. 1).

The composition and distribution of vegetation in Raczyńskie Lake was studied in 2015, at the peak of the growing season. The taxonomic composition and distribution of plant communities of reeds, plants with floating leaves and submerged plants along the shoreline of lake were analyzed. Research was carried out from a pontoon. Plant communities were determined directly in the field based on the dominant species. They were classified according to Podbielkowski and Tomaszewicz (1996) and Matuszkiewicz (2002). The occurrence and size of patches of plant communities were marked using GPS. The presence of submerged associations was checked with the weed anchor. The surface of small patches of vegetation was estimated in situ, and larger patches were calculated using ArcGIS. The abundance of associations was determined based on the size of the area occupied by phytocoenoses in square meters following the method of Kolada and Ciecierska (2008). The coastline was set on the basis of field data and aerial photographs, after which a map of the occurrence of macrophyte communities in Raczyńskie Lake and a calculation of their total surface were made using ArcGIS (Fig. 2).

The obtained results were used to calculate the Ecological State Macrophyte Index (ESMI) according to the formula given by Kolada et al. (2014). The surface of the lake was calculated on the basis of the shoreline appointed by the range of occurrence of macrophyte vegetation (94.9 ha). The potential phytolittoral area 


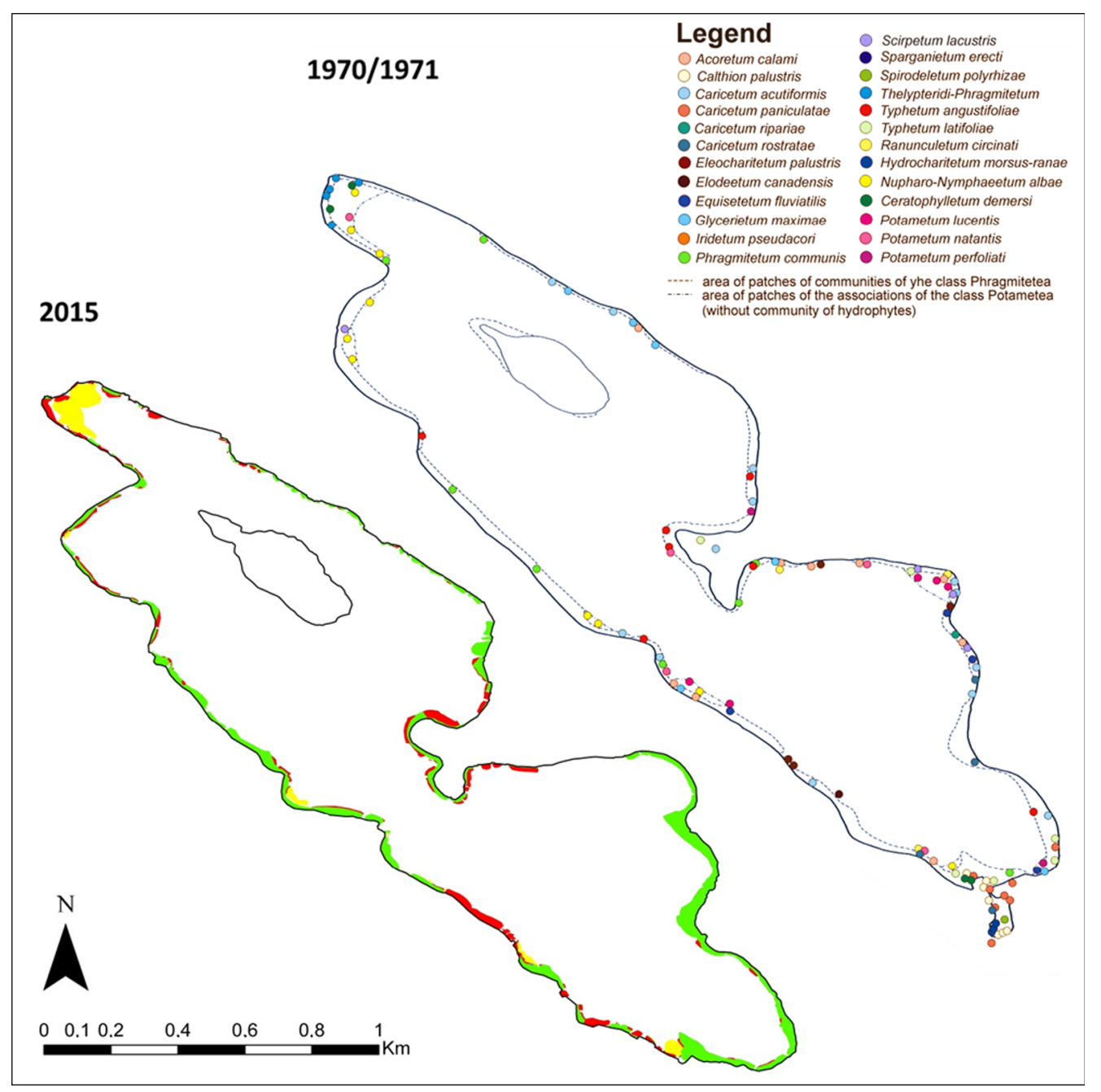

Fig. 2. Comparison of the distribution of macrophyte communities in Raczyńskie Lake in 1970/1971 (based on Gołdyn, 1975 ) and in 2015.

bounded by the $2.5 \mathrm{~m}$ isobath was calculated on the basis of a bathymetric map (33.6 ha). The ecological status of Raczyńskie Lake was assessed based on ESMI and its ranges given by the Ordinance of the Minister of Environment (2016).

The current composition and distribution of macrophyte communities occurring in Raczyńskie Lake was compared with data obtained 45 years ago, during research conducted in the period from June to September 1970 and 1971 (Gołdyn, 1975). A phytosociological characteristic was prepared at this time on the basis of 123 releves. A visual map of vegetation distribution was prepared without division into individual associations, but with indication of the exact places of the phytosociological releves (Fig. 2). The names of some communities distinguished in the 1970s were changed in accordance with currently accepted systematics of plant associations (syntaxonomic system) (Podbielkowski and Tomaszewicz, 1996; Matuszkiewicz, 2002).

\section{Results}

Based on the comparison of land use maps of Raczyńskie Lake (1980s, 2015) it was stated that the total catchment area is dominated by a field area (47\% in the 1980 s and $45 \%$ in 2015 ) and forest (37\% in the 1980 s and $35 \%$ in 2015 ), while built-up and recreational area has increased from 7\% (in the 1980s) to almost 12\% (in 2015) (Fig. 1, Tab. 3). There are far fewer forests in the area directly adjacent to the lake, with small alder forests near the south-eastern and north-western side of the lake as well as in the peninsula, while pine forest can be found in three other places at the shoreline. The old resorts are situated in two of those pine forests (Gołdyn, 1975).

Circa 13\% of the shoreline of Raczyńskie Lake was in contact with Zaniemyśl village in 1980. In the past the residential houses of this village were separated from the lake by gardens. During the last years the building area has become more compact, new streets have been created much closer to the lake and many new houses have been built. Another $13 \%$ of the shoreline was bordered by recreation resorts. They are still active, although new buildings have been created in the meantime and more people use them now. More than $70 \%$ of the rest of the shoreline was adjacent to agricultural areas, while it now borders mostly recreational or residential properties with houses and gardens. Fields and meadows are currently adjacent to the lake only over a stretch of $1400 \mathrm{~m}$, which represents about $20 \%$ of the entire shoreline. Shelterbelts (trees and bushes) at the south-eastern shore of the lake noted in 1980s has been eliminated, while at the 
Table 3. The percentage of the land use of Raczyńskie Lake catchment in the 1980 s and in 2015.

\begin{tabular}{lcr}
\hline The percentage of the land use (\%) & $1980 \mathrm{~s}$ & 2015 \\
\hline Field area & 47.1 & 44.9 \\
Forest & 37.1 & 34.9 \\
Water bodies & 8.9 & 8.6 \\
Built-up and recreational area & 6.9 & 11.7 \\
\hline
\end{tabular}

south-western shore has been narrowed down due to expanding built-up and recreational area. Three beaches were present in the early 1970 s, i.e. one in the village and two near the recreation resorts, while now bathing and angling sites are numerous in the littoral all around the lake (Pułyk, 2012). About 8000 people use the bathing sites and resorts during summer (estimated data from the local government in Zaniemyśl).

The water quality as mentioned above has deteriorated significantly in the last forty years. At present according to WFD it is classified as bad ecological status (V class) (Tab. 2). The present data of water quality variables are very high (e.g. mean concentration of chlorophyll $a 115 \mathrm{mg} \mathrm{L}^{-1}$ ), indicating hypereutrophic state.

Vegetation research conducted on Raczyńskie Lake in 2015 showed an almost typical belt system of littoral vegetation: sedges, reed beds, nympheids, except for the almost total absence of submerged associations (Fig. 2, Tabs. 4 and 5).

The total number of communities was 15 . Thirteen emergent plant associations were observed (helophytes) (Tab. 4): Phragmitetum communis, Typhetum angustifoliae, T. latifoliae, Acoretum calami, Caricetum ripariae, Caricetum acutiformis, Sparganietum erecti, Scirpetum lacustris, Eleocharitetum palustris, Thelypteridi-Phragmitetum, Glycerietum maximae, Caricetum paniculatae, and Iridetum pseudacori; one with floating leaves, Nupharo-Nymphaeetum albae, and one submerged community, Ceratophylletum demersi.

The total phytolittoral area covered by macrophytes was $c a$. 8.19 ha ( $9 \%$ of the lake area). Helophytes occupied $87 \%$, and the dominant community was $P$. communis, which covered more than $65 \%$ of the phytolittoral area. T. angustifoliae also had quite a large share of $21 \%$ (Tab. 5). Other rushes occupied small areas from 1 to $329 \mathrm{~m}^{2}$. The reeds occurred along almost the entire shoreline, whereas the bulrush community was present only in spots, often along the south-west shore. Numerous discontinuities in the belt of helophytic vegetation along the shoreline were observed. There were 96 breaks with a total length of $c a$. $920 \mathrm{~m}$ ( $15 \%$ of the shoreline length). There were also 5 bathing sites and more than 40 angling piers were observed.

Nympheids were represented by one community Nupharo-Nymphaeetum albae, which covered more than $10000 \mathrm{~m}^{2}$. This community occurred mainly in the northwest part of the lake and at the south-west bank.

A small patch of elodeids $C$. demersi appeared only in the southern part of the lake and covered approx. $22 \mathrm{~m}^{2}$.

The phytocenotic diversity index $(H)$ (which is needed to calculate ESMI index) was low (0.92), while the maximum biocenotic diversity index $\left(H_{\max }\right)$ was 2.7 . The colonization index $(Z)$ should not be less than 1.5-2.0 in reference conditions; while in good conditions should be close to 1.0 (Ciecierska and Kolada 2014). The $Z$ value in Raczyńskie Lake was 0.24. ESMI index was calculated based on the area occupied by each of the plant communities, and equated 0.087 . The corresponding ecological status of the lake according to WFD (Directive, 2000) was poor.

\section{Discussion}

The management of catchment area, especially adjacent to the lake, has a very important impact on the activation and transport of pollutants to the lake, especially nutrients (Søndergaard and Jeppesen, 2007). In addition, an increase of human pressure on the littoral zone is observed, when the number of people staying at the lake expands. The phytolittoral zone plays a key role in the functioning of aquatic ecosystems and vegetation reflects its ecological conditions (Søndergaard et al., 2013; Ciecierska and Kolada, 2014). Changes in the range and composition of vegetation, especially its disappearance, cause that nutrients from the catchment area migrate easier to the water, accelerating eutrophication of lake.

Under the influence of the prevailing environmental conditions changes occur in the structure, quality and number of macrophyte communities (Sender, 2012; Kolada et al., 2014). The vegetation can reduce its range of occurrence as well as change its composition and spatial distribution as a result of water quality deterioration (Gołdyn et al., 2010), which was constantly observed in Raczyńskie Lake over the years. Hypertrophy of this lake was caused by both intensive internal and external nutrient loading. The external load reaches the lake mainly with gradual and delayed groundwater inflow from soils polluted by sewage from leaky septic tanks from the recreational areas in the past. The increase in the number of built-up areas near the lake (Fig. 1, Tab. 3) and the destruction of the phytolittoral zone to make bathing and angling sites in Raczyńskie Lake (Fig. 2) as well as internal nutrient loading from sediments, as a result of pollution accumulated for years, also had an impact on water quality and macrophyte distribution (Zuccarini et al., 2011; Sender, 2012).

The phytocoenoses currently present in Raczyńskie Lake are commonly found in Central Europe and are typical of highly eutrophic waters (Podbielkowski and Tomaszewicz, 1996; Matuszkiewicz, 2002; Nagengast and Kuczyńska-Kippen, 2015). Plant communities belonging to the Potametea class, typical of less eutrophic waters, were also present in the years 1970-1971 as well as communities characteristic of wetland and marsh vegetation, e.g. Caricetum rostratae and Calletum palustris. The number of phytocoenoses drastically decreased in the meantime (Tab. 4, Fig. 2). During the 1970 s vegetation was typically arranged along the shores of the lake in belts. 138 aquatic and marsh plant species were found. There were 5 communities of elodeids, among which $C$. demersi was the most common (Gołdyn, 1975). Patches of Potametum lucentis were present mainly in the bay, in which fairly strong waves were common (windward side). Patches of nympheids NupharoNymphaeetum albae and Potametum natantis developed mainly in the north-western part of the lake and in the quiet, small bays along the south-western lake shore (leeward side). Other hydrophyte communities from the Potametea class were observed mainly in the vicinity of the beaches, at shallow depths. The former community of Hydrocharo-Stratiotetum began its development from the domination of Ceratophyllum 
Table 4. Taxonomic composition of macrophytes in 1970/1971 (Gołdyn, 1975) and 2015-comparison (+ present,--absent).

\begin{tabular}{|c|c|c|c|}
\hline & Macrophyte community & $1970 / 1971$ & 2015 \\
\hline & Helophytes & - & - \\
\hline 1. & Acoretum calami Kobendza 1948 & + & + \\
\hline 2. & Calletum palustris (Oswald 1923) Vanden Berghen 1952 & + & - \\
\hline 3. & Caricetum acutiformis Soó 1928 & + & + \\
\hline 4. & Caricetum paniculatae Wangerin 1916 & + & + \\
\hline 5. & Caricetum ripariae Soó 1928 & + & + \\
\hline 6. & Caricetum rostratae Rübel 1912 & + & - \\
\hline 7. & Eleocharitetum palustris Schennikow 1919 & + & + \\
\hline 8. & Equisetetum fluviatilis Steffen 1931 & + & - \\
\hline 9. & Glycerietum maximae Hueck 1931 & + & + \\
\hline 10. & Iridetum pseudacori Eggler 1933 & - & + \\
\hline 11. & Phragmitetum communis Schmale 1939 & + & + \\
\hline 12. & Scirpetum lacustris (Allorge 1922) Chouard 1924 & + & + \\
\hline 13. & Sparganietum erecti Roll 1938 & - & + \\
\hline 14. & Thelypteridi-Phragmitetum Kuiper 1957 & + & + \\
\hline 15. & Typhetum angustifoliae Soó 1927 & + & + \\
\hline \multirow[t]{2}{*}{16.} & Typhetum latifoliae Soó 1927 & + & + \\
\hline & Floating plants (Pleustophytes) & - & - \\
\hline 17. & Hydrocharitetum morsus-ranae van Langendonck 1935 & + & - \\
\hline 18. & Spirodeletum polyrhizae (Kelhofer 1954) W. Koch 1954 em. R. Tx. et A. Schwabe 1974 in R. Tx. 1974 & + & - \\
\hline \multirow[t]{2}{*}{19.} & Stratiotetum aloidis (Nowiński 1930) Miljan 1933 & + & - \\
\hline & Floating-leaved plants (Nymphaeids) & & \\
\hline 20. & Nupharo-Nymphaeetum albae Tomaszewicz 1977 & + & + \\
\hline \multirow[t]{2}{*}{21.} & Potametum natantis Soó 1923 & + & - \\
\hline & Submerged plants (Elodeids) & - & - \\
\hline 22. & Ceratophylletum demersi Hild 1956 & + & + \\
\hline 23. & Elodeetum canadensis (Pign. 1953) Pass. 1964 & + & - \\
\hline 24. & Potametum lucentis Hueck 1931 & + & - \\
\hline 25. & Potametum perfoliati Koch 1926 em. Pass. 1964 & + & - \\
\hline \multirow[t]{2}{*}{26.} & Ranunculetum circinati (Bennema et West. 1943) Segal 1965 & + & - \\
\hline & Number of communities & 24 & 15 \\
\hline
\end{tabular}

demersum and then Hydrocharis morsus-ranae with other species of the Lemnetea class reaching greater coverage. Later Stratiotes aloides dominated, proceeding sequentially to the final stage with helophytes (Gołdyn, 1975).

Significant changes in the last 45 years were visible in the case of emergent and submerge vegetation. Biodiversity was reduced as a result of the disappearance of 11 plant communities during the analyzed period (Tab. 4). In the 1970s reed beds occurred in a fairly tight belt around almost the entire shoreline of the lake (Gołdyn, 1975). This dense belt of rush vegetation has a significant impact on the reduction of external nutrient load from the catchment (Pelechaty and Pronin, 2015). Unfortunately, the zonation of vegetation in Raczyńskie Lake was destroyed by human activity in many places. The beginning of this destruction could already be seen in the 1970s (Gołdyn, 1975), but it further accelerated until 2015. Currently $15 \%$ of the shoreline is devoid of vegetation. Strong recreation pressure involving the destruction of the reed beds for the creation of numerous bathing sites, piers for fishing and jetties caused the disappearance of some rush communities, which were not recorded in 2015. Unfortunately, surface runoff from the catchment with various pollutants reaches the lake due to these numerous gaps in the reed beds, deteriorating water quality (Gołdyn et al., 2015). The research of Jusik and Macioł (2014) also showed that a significant change in the share of different ecological groups of macrophytes is observed with an increase of hydromorphological shifts.

$P$. communis and T. angustifoliae were the most common rush communities in this lake in 1970-1971. These phytocoenoses are characterized by a wide ecological amplitude (Podbielkowski and Tomaszewicz, 1996; Matuszkiewicz, 2002). According to Sender (2012), their mass development is less favorable, since they produce a large amount of organic matter and contribute to the faster ageing and disappearance of lakes. At the same time, phytocoenoses with reed domination occurred on the sandy and sandy-muddy ground, in places exposed to wind and waves, whereas a community with bulrush dominated in places with muddy-sandy and muddy ground, sheltered from the wind. A community with club-rush $S$. lacustris, occurred mainly on the windward shore (north-east), adjacent to the open water. Small patches of ThelypteridiPhragmitetum were present only in the north-western part of the lake. A sedge community $C$. acutiformis commonly occurred along the shoreline. Acorus calamus and Carex rostrata appeared between patches of other communities, which indicated their great expansiveness. Many sites with A. calamus observed in the 1970s pointed to anthropogenic changes in vegetation (Ciecierska 2006). It is worth noting that both $A$. calamus and Elodea canadensis present in the lake in the 1970s 
Table 5. The areas of particular macrophyte communities $\left(\mathrm{m}^{2}\right)$ in Raczyńskie Lake in 2015.

\begin{tabular}{ll}
\hline Community & Area $\left(\mathrm{m}^{2}\right)$ \\
\hline Phragmitetum communis & 53550 \\
Typhetum angustifoliae & 17324 \\
Nupharo-Nymphaeetum albae & 10314 \\
Typhetum latifoliae & 339 \\
Acoretum calami & 105 \\
Caricetum ripariae & 85 \\
Sparganietum erecti & 49 \\
Scirpetum lacustris & 36 \\
Eleocharitetum palustris & 35 \\
Thelypteridi-Phragmitetum & 26 \\
Ceratophylletum demersi & 22 \\
Caricetum acutiformis & 10 \\
Glycerietum maximae & 8 \\
Caricetum paniculatae & 6 \\
Iridetum pseudacori & 1 \\
Sum & 81910 \\
\hline
\end{tabular}

are alien species in Poland (Ciecierska 2006). During the 1970s $E$. palustris and C. rostratae were present in places where the natural vegetation was disturbed as a result of human impact, thus they performed a pioneering role there (Gołdyn, 1975). Currently a complete regression of patches of $C$. rostratae and limited occurrence of E. palustris were stated. Communities with floating leaves from the Nymphaeion alliance and reed beds, which were present in Raczyńskie Lake in 2015, have often been reported from lakes with high trophic state and bad ecological status (Pełechaty and Pronin, 2015).

Raczyńskie Lake, as a shallow lake, is vulnerable to the wind-induced resuspension of sediments. Thus it contributes to the mobilization of nutrients cumulated in bottom sediments and increases the trophic state, which causes excessive growth of phytoplankton (strong water blooms) and high light attenuation (James et al., 2004; Pełechaty and Pronin, 2015). The drastic reduction in light penetration was the most important factor in causing the disappearance of submerged communities in Raczyńskie Lake. This phenomenon proceeds faster in urban lakes due to pollution caused by municipal wastewaters and storm waters (e.g. Gołdyn et al., 2005; Rosińska et al., 2017). Among the species of elodeids, which were present in the 1970s but had disappeared by 2015 were: Batrachium circinatum, Chara contraria, Chara fragilis, E. canadensis, Fontinalis antipyretica, Myriophyllum spicatum, Potamogeton crispus, Potamogeton lucens, Potamogeton perfoliatus, Utricularia vulgaris. Also rarer species recorded in the 1970s: Potamogeton zizii, Wolffia arrhiza, and some species of helophytes such as Senecio paluster, Schoenoplectus tabernaemontani, Eleocharis acicularis, Leersia oryzoides, and Dianthus superbus (Gołdyn, 1975) were not observed in 2015. Even a very resistant community $C$. demersi had been almost completely eliminated; it was noted only in the south-eastern bay in 2015 . This community is an important bioindicator of highly eutrophic water bodies (bad ecological status and high trophic state) (Gołdyn et al., 2013). In addition, the presence of submerged macrophytes in lake, especially shallow, is important, as they transport and accumulate nutrients (Carpenter, 1980) as well as they limit wind-generated resuspension and nutrient release from bottom sediments (Ozimek et al., 1990; Zuccarini et al., 2011). The disappearance of this community in Raczyńskie Lake proves the complete deterioration of the water quality of this lake (Celewicz-Gołdyn, 2010) and causes increase the nutrient load in the lake.

To improve the water quality in Raczyńskie Lake it is necessary to implement protection and restoration measures which will be able to slow down the accelerated eutrophication, eliminate cyanobacterial water blooms and improve light conditions. The construction of a wastewater network in the catchment area of the lake and sewage diversion to a treatment plant was an important step. Now lake restoration is necessary; decreasing its trophic status will lead to the return of submerged macrophytes and to the growth of helophytes and nympheids in the lake. Well-developed vegetation, i.e. high phytocenotic diversity, will maintain good water quality (Ciecierska and Kolada, 2014; Pełechaty and Pronin, 2015). However, it should be noted that restoration processes are long-term (Grochowska et al., 2015), and the reconstruction of macrophytes can be limited by many factors, i.a. lack of diasporas, poor light conditions at the bottom, sediment resuspension and the feeding of waterfowl and fish (van de Haterd and Ter Heerdt, 2007; Gołdyn et al., 2013; Klimaszyk et al., 2015).

\section{Conclusions}

Strong human impact, mainly the development of diverse forms of recreation at the shoreline of Raczyńskie Lake, have resulted in increased external nutrient loading and the permanent deterioration of water quality, in particular of light conditions as a result of strong water blooms. This has led to a reduction of vegetation biodiversity over the last 45 years, in particular the almost complete disappearance of submerged vegetation. Only a small patch of the most resistant association $C$. demersi has survived. The abundant development of reed beds ( $P$. communis, $T$. angustifoliae) has been destroyed in many places by human activity creating fishing and bathing sites, jetties, etc. and they no longer provide an effective barrier against pollutants from the catchment. It is necessary to implement protection and restoration measures to slow down the progressive eutrophication of the lake, and it is likely that a reintroduction of some species of submerged plants will be also required due to their total lack in the lake.

Acknowledgements. We would like to thank Michał Rybak for graphical help, PhD Renata Dondajewska for catchment determination and Kasia Pędziwiatr for ArcGIS help. The research was supported by the Fund for the statutory activities of the Department of Water Protection.

\section{References}

Barałkiewicz D, Chudzińska M, Szpakowska B, Świerk D, Gołdyn R, Dondajewska R. 2014. Storm water contamination and its effect on the quality of urban surface waters. Environ Monit Assess 186: 6789-6803.

Carpenter SR. 1980. The decline of Myriophyllum spicatum in a eutrophic Wisconsin lake. Can J Bot 58: 527-535.

Celewicz-Gołdyn S. 2010. Influence of Ceratophyllum demersum L. on phytoplankton structure in a shallow eutrophic lake. Oceanol Hydrobiol Stud 39: 121-128. 
Ciecierska H. 2006. Evaluation of the status of lakes located in the City of Olsztyn (Masurian Lake District, N-E Poland ) by the macrophytoindication method (MPhI). Hydrobiologia 570: 141-146.

Ciecierska H, Kolada A. 2014. ESMI: a macrophyte index for assessing the ecological status of lakes. Environ Monit Assess 186: 5501-5517.

Directive. 2000. Directive 2000/60/EC of the European Parliament and of the Council of 23 October 2000 establishing a framework for Community action in the field of water policy. OJL 327: 1-73.

Dunalska JA, Grochowska J, Wis niewski G Napiórkowska-Krzebietke A. 2015. Can we restore badly degraded urban lakes? Ecol Eng 82: 432-441.

Gołdyn R. 1975. Plant communities of Raczyńskie Lake near Zaniemys 1. Badania fizjograficzne nad Polską Zachodnią, Seria B. Botanika 28: 49-87.

Gołdyn R, Gołdyn H, Kaniewski W. 2005. Water plant associations in the valley of the Cybina River. Rocz. AR Pozn. 373. BotanicaSteciana 9: 69-87.

Gołdyn B, Kowalczewska-Madura K, Celewicz-Gołdyn S. 2015. Drought and deluge: influence of environmental factors on water quality of kettle holes in two subsequent years with different precipitation. Limnologica 54: 14-22.

Gołdyn R, Podsiadłowski S, Kowalczewska-Madura K, Dondajewska R, Szeląg-Wasielewska E, Budzyńska A, Domek P, RomanowiczBrzozowska W. 2010. Functioning of the Lake Rusałka ecosystem in Poznań (western Poland). Oceanol Hydrobiol Stud 39: 65-80.

Gołdyn R, Messyasz B, Domek P, Windhorst W, Hugenschmidt C, Nicoara M. 2013. The response of Lake Durowskie ecosystem to restoration measures. Carpath J Earth Environ Sci 8: 43-48.

Grochowska J, Brzozowska R, Łopata M, Dunalska J. 2015. Influence of restoration methods on the longevity of changes in the thermal and oxygen dynamics of a degraded lake. Oceanol Hydrobiol Stud 44: 18-27.

Hall CM, Härkönen T. 2006. Lake tourism: an introduction to lacustrine tourism systems. Aspects of Tourism 32: 3-26.

James WF, Best EP, Barko JW. 2004. Sediment resuspension and light attenuation in Peoria Lake: can macrophytes improve water quality in this shallow system? Hydrobiologia 515: 193-201.

Jusik S, Macioł A. 2014. The influence of hydromorphological modifications of the littoral zone in lakes on macrophytes. Oceanol Hydrobiol Stud 43: 66-76.

Klimaszyk P, Piotrowicz R, Rzymski P. 2015. Changes in physicochemical conditions and macrophyte abundance in a shallow softwater lake mediated by a great cormorant roosting colony. J Limnol 74: $114-122$.

Kolada A, Ciecierska H. 2008. Methods for lake macrophyte surveying in the light of biological monitoring required by Water Framework Directive. Environ Prot Nat Res 37: 9-23 (in Polish).

Kolada A, Ciecierska H, Ruszczyńska J, Dynowski P. 2014. Sampling techniques and inter-surveyor variability as sources of uncertainty in Polish macrophyte metric for lake ecological status assessment. Hydrobiologia 737: 265-279.

Lombardo P, Mjelde M, Källqvist T. Brettum P. 2013. Seasonal and scale-dependent variability in nutrient- and allelopathy-mediated macrophyte-phytoplankton interactions. Knowl Manag Aquat Ecosyst 409: 10.

Matuszkiewicz W. 2002. A guide book to identification plant communities in Poland, Warszawa: PWN Sci Publ, 536 p (in Polish).

Nagengast B, Kuczyńska-Kippen N. 2015. Macrophyte biometric features as an indicator of the trophic status of small water bodies. Oceanol Hydrobiol Stud 44: 38-50.
Ordinance of the Minister of Environment. 2011. Ordinance of the Minister of Environment dated 9 November 2011 on the classification of status of surface water bodies and environmental quality standards for priority substances, Dz. U. 2011, item 1545 (in Polish).

Ordinance of the Minister of Environment. 2016. Ordinance of the Minister of Environment dated 21 July 2016 on the classification of status of surface waterbodies and environmental quality standards for priority substances, Dz.U. 2016, item 1187 (in Polish).

Ozimek T, Gulati RD, van Donk E. 1990. Can macrophytes be useful in biomanipulation of lakes? The Lake Zwemlust example. Hydrobiologia 200-201: 399-407.

Pełechaty M, Pronin E. 2015. The role of aquatic and rush vegetation in the functioning of lakes and assessment of the state of their waters. Studia Limnologica et Telmatologica 9: 25-34.

Penning WE, Mjelde M, Dudley B, Hellsten S, Hanganu J, Kolada A, van den Berg M, Poikane S, Phillips G, Willby N, Ecke F. 2008. Classifying aquatic macrophytes as indicators of eutrophication in European lakes. Aquatic Ecol 42: 237-251.

Podbielkowski Z, Tomaszewicz H. 1996. A guide to hydrobotany, Warszawa: PWN Sci. Publ., 530 p (in Polish).

Pułyk M. 2012. Report of the state of the environment in Wielkopolska in 2011, Biblioteka Monitoringu Środowiska, Poznań (in Polish).

Pułyk M, Buczyńska E. 1997. Surface water quality in the Kopla river catchment based on monitoring studies, Biblioteka Monitoringu Środowiska, Poznań (in Polish).

Pułyk M, Koziarska M. 2014. Information of the state of the environment and control activities of the Wielkopolska Inspector Provincial Environmental Protection in Średzki District in 2013, WIOS , Poznań (in Polish).

Pułyk M, Tybiszewska E. 2002. Report of the state of the environment in Wielkopolska in 2001, Biblioteka Monitoringu Środowiska, Poznań (in Polish).

Rosińska J, Rybak M, Gołdyn R. 2017. Patterns of macrophyte community recovery as a result of the restoration of a shallow urban lake. Aquat Bot 138: 45-52.

Scheffer M, Hosper SH, Meijer M-L., Moss B, Jeppesen E. 1993. Alternative equilibria in shallow lakes. Trends Ecol Evol 8: 275-279.

Schmieder K. 2004. European lake shores in danger - concepts for sustainable development. Limnologica 34: 3-14.

Sender J. 2012. The dynamics of macrophytes in a lake in an agricultural landscape. Limnol Rev 12: 93-100.

Søndergaard M, Jeppesen E. 2007. Anthropogenic impacts on lake and stream ecosystems, and approaches to restoration. $J$ Appl Ecol 44: 1089-1094.

Søndergaard M, Phillips G, Hellsten S, Kolada A, Ecke F, Mäemets H, Mjelde M, Azzella MM, Oggioni A. 2013. Maximum growing depth of submerged macrophytes in European lakes. Hydrobiologia 704: 165-177.

van de Haterd RJW, Ter Heerdt GNJ. 2007. Potential for the development of submerged macrophytes in eutrophicated shallow peaty lakes after restoration measures. Hydrobiologia 584: 277-290.

Xu ZH, Yin XA, Yang ZF. 2014. An optimisation approach for shallow lake restoration through macrophyte management. Hydrol Earth Syst Sci 18: 2167-2176.

Zuccarini P, Ciurli A, Alpi A. 2011. Implications for shallow lake manipulation: results of aquaria and enclosure experiments manipulating macrophytes, zooplankton and fish. AEER 9: $123-140$. 